\title{
Improved efficacy of neonicotinoid in tablet formulation on the control of tomato chlorosis virus by controlling the vector Bemisia tabaci
}

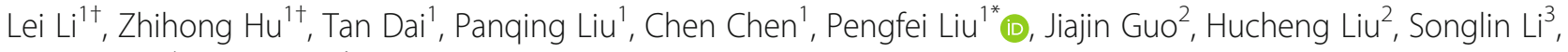 \\ Jianjun $\mathrm{HaO}^{4}$ and Xili Liu ${ }^{1}$
}

\begin{abstract}
Neonicotinoid insecticides are used for preventing insects from transmitting plant viruses. This group of chemicals are easily taken up by plants and translocated to different tissues and are applicable for soil treatment in sustainedrelease tablets, which greatly reduces environmental contamination compared to foliar spray. The goal of this study was to examine the efficacy of thiamethoxam, acetamiprid and nitenpyram in tablet formulation against whitefly, Bemisia tabaci, the vector of tomato chlorosis virus (ToCV) under laboratory and greenhouse conditions. Effective $50 \%$ lethal concentration ( $\left(\mathrm{C}_{50}\right)$ of thiamethoxam, acetamiprid, and nitenpyram on $\mathrm{B}$. tabaci were $2.18,0.46$ and $0.18 \mathrm{\mu g} / \mathrm{g}$ plant tissue, respectively. In vitro test showed that tablets of $10 \mathrm{mg}$ nitenpyram applied in seedbed with thiamethoxam transplanting treatment showed $80.9 \%$ control of B. tabaci on tomato and $75.5 \%$ of ToCV after 32 days of transplanting. Therefore, neonicotinoid tablets were an effective strategy of soil treatment in controlling viruliferous insects and ToCV with reduced environmental contamination.
\end{abstract}

Keywords: Sustained release tablets, Insecticide, Chemical control, Whitefly

\section{Background}

Vegetable crops have been threatened by viral diseases that cause significant economic losses (Dáder et al. 2015; Tolin and Fayad 2016), and tomato chlorosis virus (ToCV) is one of the pathogenic agents leading to the diseases. ToCV can reduce the vigor of tomato plant and lead to a significant decline in fruit production (Zhao et al. 2014). For directly suppressing plant viruses, no effective chemicals are available. Instead, viruses may be controlled by management of virus-spreading vectors (Roditakis et al. 2017; Zheng et al. 2017). Previous studies have shown that ToCV is transmitted by whitefly, Bemisia tabaci (Wintermantel and Wisler 2006; Orfanidou et al. 2014). Neonicotinoids insecticides, a group of systemic chemicals, have been widely used to control

\footnotetext{
* Correspondence: pengfeiliu@cau.edu.cn

${ }^{\dagger}$ Lei Li and Zhihong Hu contributed equally to this work.

${ }^{1}$ Department of Plant Pathology, China Agricultural University, Beijing

100193, China

Full list of author information is available at the end of the article
}

piercing sucking insects (Kodandaram et al. 2017) including B. tabaci. These chemicals can be easily absorbed by and translocated in plants. The downside of using this product group, however, is the risk of environmental contamination if applied on foliage (Byrne et al. 2007; Gill et al. 2012; Hallmann et al. 2014).

To take the advantage of the highly effective insecticides, neonicotinoids, while reducing environmental contamination, an improved technique of pesticide application needs to be proposed. Seed treatment with neonicotinoids is one effective technique (Douglas and Tooker 2015), but chemicals in the coating layer can be quickly released, resulting in a limited period of effectiveness (Ekbom and Müller 2011; Kennedy and Connery 2012). Alternatively, tablet formulation can improve the product efficiency (Castle et al. 2009). The tablet formulation allows chemicals to be slowly released and therefore can extend the period of effective action. This method also offers an environmentally safer alternative (Prudnikova et al. 2013; Volova et al. 2017). Tablets are 
easy to store and transport and are less toxic to plants and human beings (Zhang 1993).

Effective prevention of viral diseases starts at an early stage of seedlings. Neonicotinoids tablets can be applied at seeding or transplanting period, which stop whitefly in seedbed and transplanting stage, and therefore can effectively prevent the spreading of viral diseases. The objectives of this work were to determine the efficacy of neonicotinoids (thiamethoxam, acetamiprid and nitenpyram) in tablet formulation, their safe dosages, best time of application under laboratory and greenhouse conditions; and to validate the effect of these neonicotinoids insecticds on whitefly and ToCV under field conditions after transplanting.

\section{Results}

$\mathrm{LC}_{50}$ of thiamethoxam, acetamiprid and nitenpyram on $B$. tabaci

To determin the effective leathal concentration of neonicotinoid in plants on B. tabaci, biological assay together coupled with HPLC analysis were applied. Mortality rate of B. tabaci ranged from 1.81 to $94.27 \%$ when tomato leaves were soaked in aqueous solution of thiamethoxam from 2 to $100 \mu \mathrm{g} / \mathrm{mL}$ in advance, and no B. tabaci died at concentrations of thiamethoxam lower than $2 \mu \mathrm{g} / \mathrm{mL}$ (Fig. 1). The mortality rate of B. tabaci ranged from 2.64 to $100 \%$ when treated with 0.5 to $10 \mu \mathrm{g} / \mathrm{mL}$ of acetamiprid, and from 10 to $100 \%$ with 0.5 to $10 \mu \mathrm{g} / \mathrm{mL}$ of nitenpyram. All whiteflies were dead when treated with either acetamiprid or nitenpyram at concentrations higher than $10 \mu \mathrm{g} / \mathrm{mL}$. Under the same conditions, mortality rate in untreated control was $0 \%$. Therefore, the bioactivity of acetamiprid and nitenpyram on whiteflies was more effective than thiamethoxam. The detected concentrations of thiamethoxam, acetamiprid and nitenpyram in soaking solutions were in accordance with the regression equation as $y=0.0678 x+0.2776\left(R^{2}=0.9956\right), y=0.0834 x+0.1766$ $\left(R^{2}=0.9997\right)$ and $y=0.0744 x+0.037\left(R^{2}=0.9986\right)$, where $y$ represents probability of inhibition and $x$ represents logarithmic transformation of chemical concentration applied.

A HPLC method was established for analyzing three neonicotinoids. Retention times of standard compounds were $5.78,10.75$ and $5.48 \mathrm{~min}$ for thiamethoxam, acetamiprid and nitenpyram, respectively. The recovery of the three compounds ranged from 88.5 to $98.7 \%$ with relative standard deviation (RSD) from 1.3 to $6.5 \%$. The concentration of each tested neonicotinoid insectcide in tomato leaves was determined by HPLC. Toxicity regression equation of thiamethoxam, acetamiprid and nitenpyram on $B$. tabaci was determined as $y=2.74 x+4.07$ $\left(R^{2}=0.98\right), \quad y=4.71 x+6.58 \quad\left(R^{2}=0.91\right), \quad y=3.45 x+7.61$ $\left(R^{2}=0.99\right)$, where $y$ represents probability of inhibition and $x$ represents logarithmic transformation of chemical concentration in plant. $\mathrm{LC}_{50}$ was $2.18,0.46$ and $0.18 \mu \mathrm{g} / \mathrm{g}$ fresh plant for thiamethoxam, acetamiprid and nitenpyram, respectively.

\section{Impact of tablets of thiamethoxam, acetamiprid and nitenpyram on emergence and growth of tomato seedlings}

None of the three insecticides in tablets affected the emergence of tomato (Additional file 1: Table S1), but had different effects on the growth of tomato seedlings. Tomato roots and leaves were deeply injured with acetamiprid tablets at $1 \mathrm{mg} /$ plant and thiamethoxam at $>5$ mg/plant. Dehydration of the leaf margins caused by these two insectcides occured at concentrations lower than that for injury (Fig. 2). As the concentration of thiamethoxam and acetamiprid increased, seedling defoliation

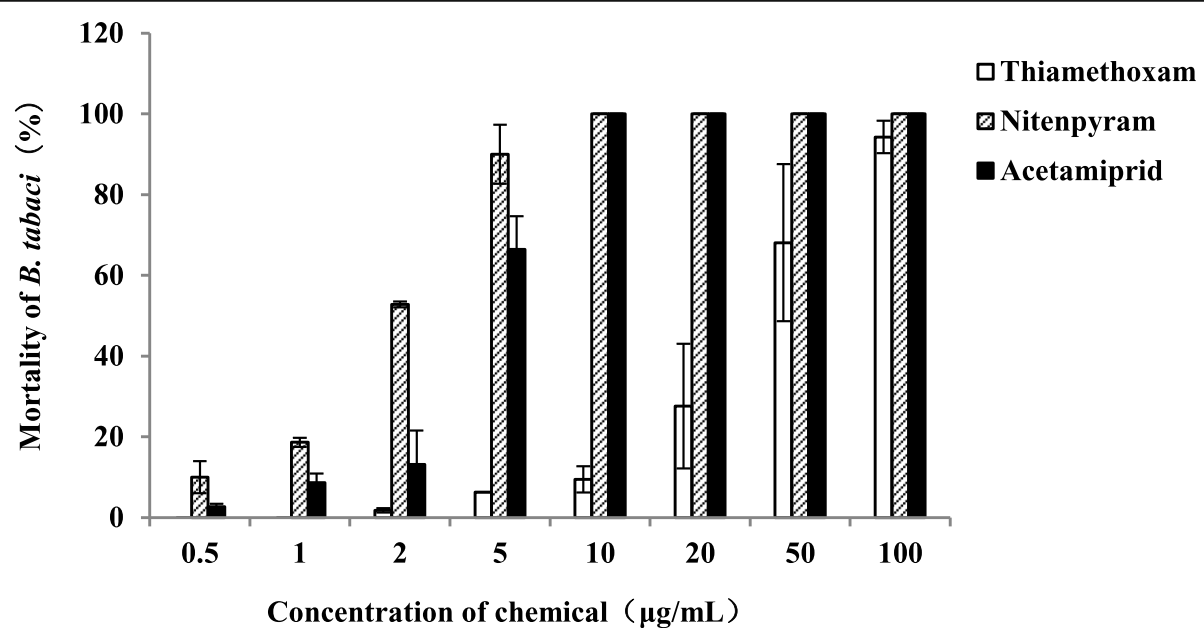

Fig. 1 Toxicity of three insecticides against Bemisia tabaci. Mortality rate in untreated control is $0 \%$. Rectangular bars represent mean values, which were marked with standard deviation. The $x$-axis shows the concentrations of the pesticide solutions used for leaf soaking 


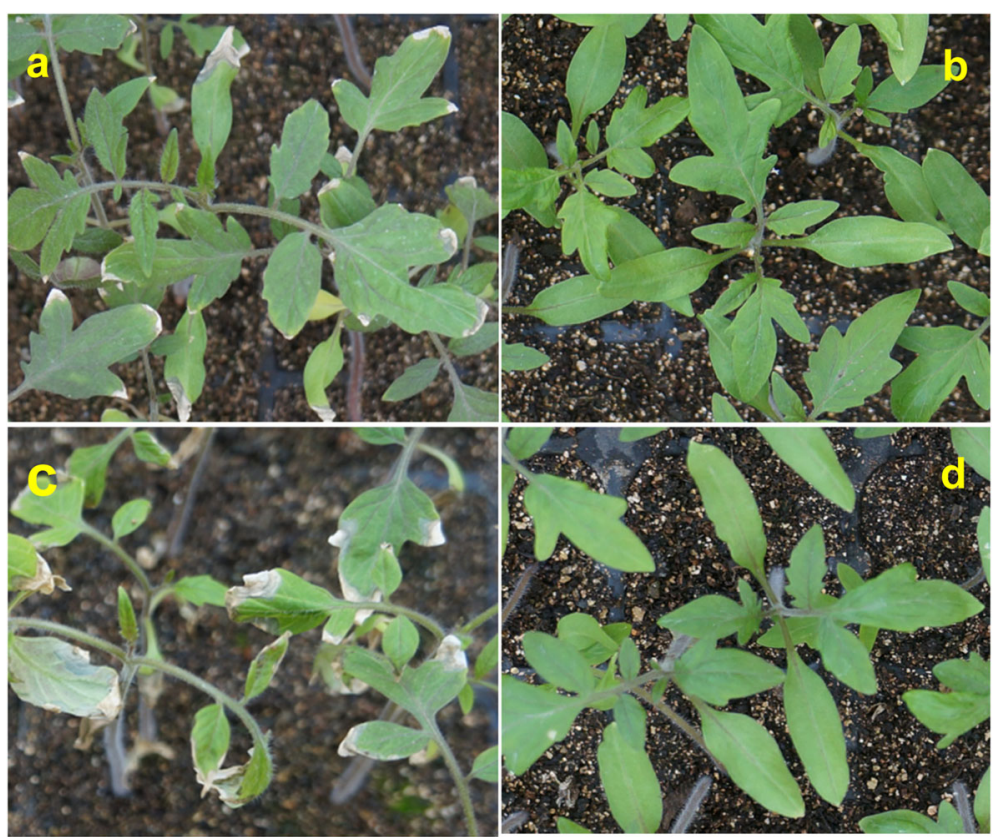

Fig. 2 Effects of pesticide tablets on tomato seedling in seedbed. Tomato seedlings treated by tablets containing 10 mg thiamethoxam (a), 10 mg nitenpyram (b), $1 \mathrm{mg}$ acetamiprid (c), and no chemicals for control (d). Leaf surface injury was found 14 days after emergence

and poorly developed roots occurred. Leaf surface of tomato seedlings was not injured by thiamethoxam tablets at concentrations lower than $5 \mathrm{mg} /$ plant, but plant height was significantly suppressed at 1 and $2 \mathrm{mg} /$ plant. Tomato seedlings were more tolerant to nitenpyram at set doses except $15 \mathrm{mg} / \mathrm{plant}$, at which tips of tomato leaves gradually turned yellow 7 days after emergence. Therefore, thiamethoxam and nitenpyram were selected for further study and acetamiprid was removed from the test list.

\section{Absorption and translocation of nitenpyram and thiamethoxam in tomato plants}

Leaves of tomato plants under the treatment of nitenpyram tablets at 5,10 and $15 \mathrm{mg}$ and thiamethoxam at 1,2 and $5 \mathrm{mg}$ were collected at 7 to 42 days after seed emergence with a 7-day interval to detect the uptake of pesticides in tomato plants. Nitenpyram was detected at 12.55 to $46.28,30.79$ to 102.07 and 14.89 to $111.99 \mu \mathrm{g} / \mathrm{g}$ corresponding to tablet dose of 5,10 and $15 \mathrm{mg}$, respectively (Fig. 3). Insecticide content detected in the seedlings treated with $10 \mathrm{mg}$ nitenpyram was approximately twice that with $5 \mathrm{mg}$. However, for the treatment with $15 \mathrm{mg}$ nitenpyram, the amount of insecticide taken up into plants did not further increase as expected. Thiamethoxam of 12.47 to $15.58,11.89$ to 33.38 and 68.85 to $192.73 \mu \mathrm{g} / \mathrm{g}$ were detected corresponding to tablet of 1 , 2 , and $5 \mathrm{mg}$, respectively within 42 days. The concentration of both chemicals in plants reached a peak 7 days after emergence at 10 and $15 \mathrm{mg}$ nitenpyram and $5 \mathrm{mg}$ thiamethoxam. However, with lower doses, the concentration reaching to peak was extended to 14 days after emergence for nitenpyram at $5 \mathrm{mg}$ and thiamethoxam at $2 \mathrm{mg}$ and $1 \mathrm{mg}$. Following the peak time, both chemicals started declining (Fig. 3).

\section{Effects of soil application of neonicotinoid tablets on $B$. tabaci and ToCV}

Whitefly control at seedling stage and after transplanting

In the pot experiment, mortality rate of $B$. tabaci treated with neonicotinoid tablets was from 90 to $98 \%$ between 14 and 28 days after planting (Fig. 4), and no symptoms of ToCV was observed on the insectide-treated plants.

Owing to a strict management in seedling cultivation factory, whitefly population in tomato fields was very low in the period from seed emergence to seedling transplanting stages with or without treatment of nitenpyram tablet $(5$ and $10 \mathrm{mg}$ ) at seeding. Thiamethoxam $(40 \mathrm{mg})$ tablet used at transplanting obtained the whitefly control ranging from 79.5 to $83.2 \%$ on the 32nd day, and from 56.1 to $62.9 \%$ on the 46 th day (Table 1). The control efficacy of whitefly on the 32 nd day was much higher than that on the 46th day. The best control efficacy of pesticide tablet was achieved by nitenpyram $(10 \mathrm{mg})$ treatment at seeding followed by thiamethoxam $(40 \mathrm{mg})$ at transplanting, which was $4.1 \%$ lower than that of thiamethoxam $(60 \mathrm{~g}$ 


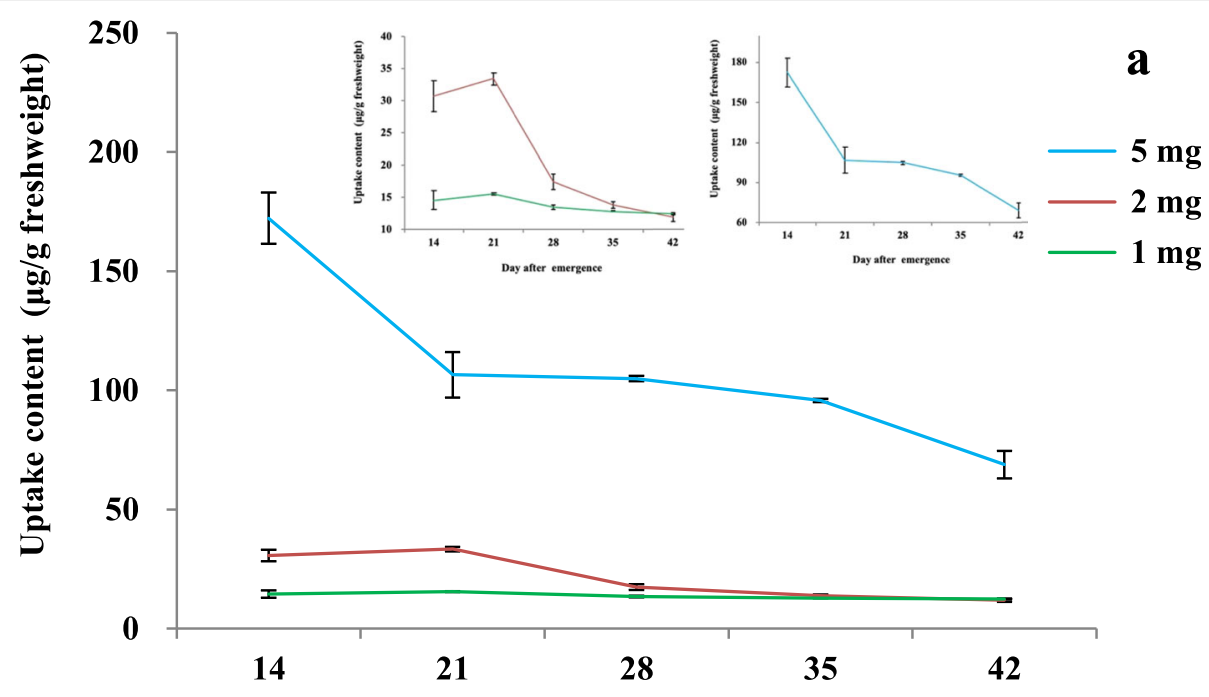

Days after emergence

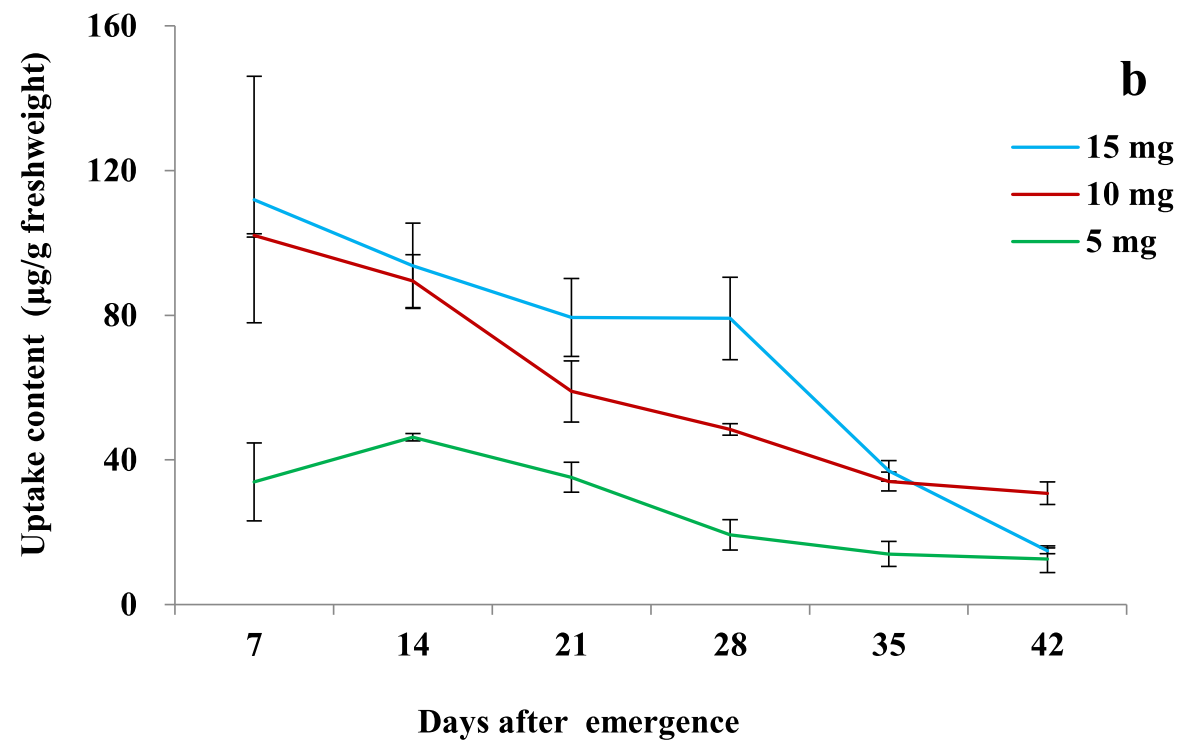

Fig. 3 Uptake of thiamethoxam (a) and nitenpyram (b) in tomato plants after emergence

a.i./ha) on foliage. Though, the effect of insects control was good enough.

\section{ToCV control after transplanting}

Symptoms of ToCV were not found on tomato plants until 20 days after transplanting, when some faded green spots or slight chlorosis were observed on main veins of leaves or basal leaf blades of the non-treated plants. Symptoms were not observed on tablet-treated leaves until 30 days after transplanting.
Compared with the ToCV disease index of nontreated plants (Table 1), both foliar spray with regular formulated product and soil application with tablet resulted in significant control on ToCV. Disease intensity progressively increased during the evaluation period, which was shown by significant disease index increase from 32 to 46 days after transplanting. Tablets of nitenpyram with seed sown at $5 \mathrm{mg}$ and $10 \mathrm{mg}$ followed by $40 \mathrm{mg}$ thiamethoxam at transplanting, showed the highest level of control against ToCV. Disease control reached $70.3 \%$ and $75.8 \%$ by the tablet treatments, which 


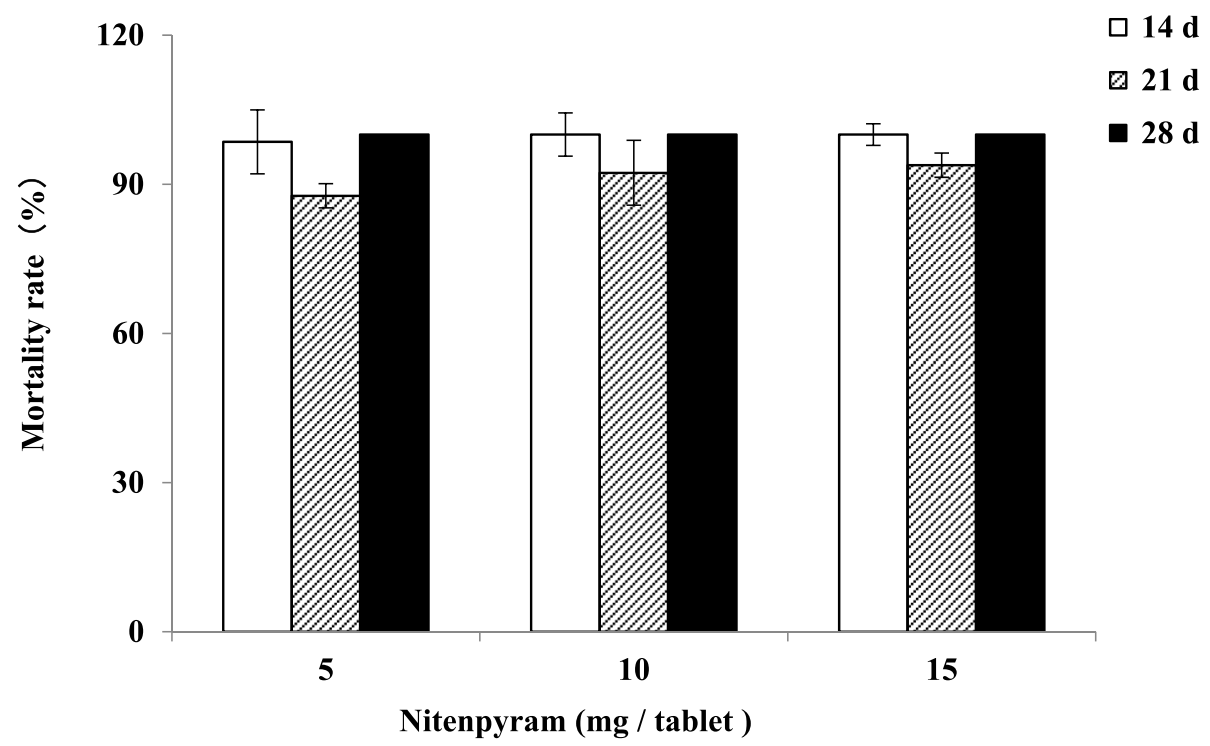

Fig. 4 Effects of nitenpyram tablets on Bemisia tabaci in seedbed, measured at 14, 21, and 28 days after planting. Mortality rate of $B$. tabaci in untreated control is $0 \%$

were about $20 \%$ more than thiamethoxam foliage spray, and $12 \%$ more than that of tablets applied only on transplanting.

\section{Discussion}

Sustained-release dosage forms of pesticide include microcapsule, tablet, pellet, granule, and seed coating agent, which hold the active ingredient to be released slowly over a prolonged period of time. These dosage formulations are of great importance in reducing the loss of active ingredients in the environment, increasing utilization, reducing usage rate and the cumulative residual toxicity. Neonicotinoids are usually characterized by long persistence (Anderson et al. 2015; Struger et al. 2017) and are very suitable for soil treatment in the form of tablets at sowing (Jeschke et al. 2011). According to the characteristics of the pesticides and the occurrence of pests and diseases, appropriate time and application method should be selected to achieve safe and effective control.

Neonicotinoids are systemic pesticides that can be absorbed by tomato roots when applied in soil and translocated in plants. Through systemic movement in plants, these chemicals show a high level of toxicity against pests above ground (Huseth et al. 2014). The concentration of insecticides in plants has been associated with the uptake content. The uptake efficiency in tomato seedlings of thiamethoxam was much higher than that of nitenpyram, indicating thiamethoxam was easier to be absorbed and transmitted in tomato seedlings than nitenpyram. This helps plants prevent insect damage, but may be unsafe to the seedlings due to

Table 1 Effect of neonicotinoid tablets on Bemisia tabaci and tomato chlorosis virus measured on days 32 and 46 after transplanting

\begin{tabular}{|c|c|c|c|c|c|c|}
\hline \multirow[t]{2}{*}{ Treatment /plant } & \multicolumn{2}{|c|}{ Whitefly control (\%) } & \multicolumn{2}{|c|}{ Disease index (\%) } & \multicolumn{2}{|c|}{ Disease control (\%) } \\
\hline & $32 \mathrm{~d}$ & $46 \mathrm{~d}$ & $32 \mathrm{~d}$ & $46 \mathrm{~d}$ & $32 \mathrm{~d}$ & $46 d$ \\
\hline Tablet of nitenpyram ( $5 \mathrm{mg}$ ) on seed & $48.9 \mathrm{C}$ & $30.1 \mathrm{c}$ & $6.2 \mathrm{~b}$ & $15.2 \mathrm{~b}$ & $31.9 \mathrm{~d}$ & $16.0 \mathrm{C}$ \\
\hline Tablet of nitenpyram $(10 \mathrm{mg})$ on seed & $51.2 \mathrm{c}$ & $35.0 \mathrm{c}$ & $4.0 \mathrm{~cd}$ & $13.7 \mathrm{c}$ & $56.0 \mathrm{bc}$ & $24.3 \mathrm{~b}$ \\
\hline $\begin{array}{l}\text { Tablet of nitenpyram }(5 \mathrm{mg}) \text { on seed followed by thiamethoxam } \\
(40 \mathrm{mg}) \text { at transplanting }\end{array}$ & $79.5 \mathrm{~b}$ & $56.1 \mathrm{~b}$ & $2.7 \mathrm{e}$ & $10.7 d$ & 70.3 a & $40.9 \mathrm{a}$ \\
\hline $\begin{array}{l}\text { Tablet of nitenpyram }(10 \mathrm{mg}) \text { on seed followed by thiamethoxam } \\
(40 \mathrm{mg}) \text { at transplanting }\end{array}$ & $80.9 \mathrm{ab}$ & $57.2 \mathrm{~b}$ & $2.2 \mathrm{e}$ & $10.9 \mathrm{~d}$ & $75.8 \mathrm{a}$ & $39.8 \mathrm{a}$ \\
\hline Tablet of thiamethoxam $(40 \mathrm{mg})$ at transplanting & $83.2 \mathrm{ab}$ & $62.9 \mathrm{a}$ & $3.8 \mathrm{~cd}$ & $13.8 \mathrm{C}$ & $58.2 b$ & $23.8 \mathrm{~b}$ \\
\hline Thiamethoxam (60 g a.i./ha) on foliage & $85.0 \mathrm{a}$ & $63.9 \mathrm{a}$ & $4.4 \mathrm{C}$ & $13.2 \mathrm{C}$ & $51.6 c$ & $27.1 \mathrm{~b}$ \\
\hline Non-treated control & - & - & $9.1 \mathrm{a}$ & $18.1 \mathrm{a}$ & - & - \\
\hline
\end{tabular}

The values within each column followed by different letters differ significantly $(P \leq 0.05)$. The infestation with $B$. tabaci in non-treated control was 136.4 per plant 
phytotoxicity. In this study, both thiamethoxam and acetamiprid could damage young seedlings after a high dose was taken into the plant. The activity of three neonicotinoids against adult B. tabaci B-type were ranked from high to low: nitenpyram > acetamiprid > thiamethoxam. Escepically, the nitenpyram tablet formulation combined high plant safety with high insecticidal activity.

Soil application of tablets with 5 or $10 \mathrm{mg}$ nitenpyram allowed plants to absorb sufficient doses to kill B. tabaci, and therefore effectively prevented ToCV before transplanting. This helped to control the disease at seedling stage post transplanting. $\mathrm{LC}_{50}$ of nitenpyram was determined as $0.18 \mu \mathrm{g} / \mathrm{g}$ fresh plant in this study, which was significantly lower than previously reported (Wang et al. 2017). This is mainly because the concentrations in this study were detected in fresh leaves by HPLC, while those reported in literature (Wang et al. 2017) were normally the concentrations of pesticides active ingredient in water sprayed on leaves.

All treatments had similar effects on controlling ToCV and significantly reduced the disease it caused. However, nitenpyram in tablet formulation applied in soil at sowing was more effective than in suspension formulation applied by foliar spray, which suggested that controlling B. tabaci can reduce the occurrence of tomato chlorosis virus disease at the nursery stage. ToCV could be spread by whiteflies and invade tomato seedlings in seedbed, but did not result in visually apparent symptoms at an early stage. Therefore, the seedbed stage was a critical period for ToCV control.

We have shown that seeds sowed with nitenpyram tablets ensured tomato plant to be more resistant to ToCV. As plants matured, insecticide concentration decreased in plants. When the tomato plants were about to enter the flowering period, the insecticides were mostly released from the tablets. Therefore, a secondary application of the insecticides was required. For example, $\mathrm{YITE}^{\oplus}$ tablets are suggested to be applied twice during the whole plant growing period based our investigation (unpublished data).

Early prevention and control of B. tabaci could delay the occurence of tomato chlorosis virus disease and reduce disease severity at a later stage, which favored tomato plants for normal photosynthesis, growth and flowering. The dose of pesticide tablets used at seeding needed to be based on the infestation level of $B$. tabaci. Our results showed that using tablets of $5 \mathrm{mg}$ nitenpyram at tamato sowing stage was sufficient to control the initial infestation of B. tabaci. After transplanting, tablets should be used in a 3- or 4-week interval during pest's active season. The use of tablets not only controlled $\mathrm{ToCV}$ at an early stage, but also could reduce foliar sprays after transplanting, thus decreasing pesticide release in an environmentally sound and safe manner over the whole growing season.

\section{Conclusions}

A tablet is a sustained release formulation that can be used for soil treatment, as it contains high dose of chemicals, releases slowly, and possesses long validity. The application of neonicotinoid tablets were effective for soil treatment to prevent the spread of tomato chlorosis virus by controlling its insect vector, $B$. tabaci. The highest dose of nitenpyram was recommended at $10 \mathrm{mg}$ per plant by seed treatment, and the persistent period can last for more than 1 month, thus ensuring the normal growth of plants, and maintaining a high yield.

\section{Methods}

Technical grade of acetamiprid (a.i. 97.3\%), thiamethoxam (a.i. 95.4\%), and nitenpyram (a.i. 97.3\%) were obtained from Shandong Sino-Agri United Biotechnology Co., Ltd. (Jinan, China). Analytical standards of the pesticides were obtained from Shanghai Institute for Food and Drug Control (Shanghai, China). GCB, PSA and $\mathrm{C} 18$ were obtained from Agilent Technologies (Beijing, China). $\mathrm{MeOH}$ (HPLC grade) was provided by Fisher Scientific (Shanghai, China). Pure water was obtained from a Milli-Q device (Millipore Crop, Beford, MA, USA). Other reagents (analytical grade) were provided by Beijing Chemical Works (Beijing, China). Product YITE $^{\oplus}$ Tablet, containing $40 \mathrm{mg}$ thiamethoxam (a.i.), $10 \mathrm{mg}$ starch, $10 \mathrm{mg}$ surfactants and $140 \mathrm{mg}$ bentonite per tablet, was provided by Baoding Shunnong Plant Protection Limited Company (Hebei, China). Pesticide tablets containing either acetamiprid, thiamethoxam or nitenpyram were prepared with a weight of $200 \mathrm{mg}$ containing active ingredients (1-40 mg a.i.), starch (10 mg), surfactants $(10 \mathrm{mg})$ and bentonite $(179-140 \mathrm{mg})$. Pesticides were milled to median particle diameter of $10 \mu \mathrm{m}$ by fluid energy milling (BKY100, Kunshan Boké Smash Equipment Co., Ltd.) before tableting. Actara ${ }^{\bullet}$ (Syngenta, Shanghai, China) is a formulation of water dispersible granule containing $25 \%(\mathrm{w} / \mathrm{w})$ thiamethoxam.

B-biotype B. tabaci was provided by the Institute of Vegetables and Flowers, Chinese Academy of Agricultural Sciences. Whitefly colonies were maintained in a growth chamber at a photoperiod of $16: 8 \mathrm{~h}$ (light:dark), $28 \pm 2{ }^{\circ} \mathrm{C}$ and $50 \%-60 \%$ relative humidity (RH). Tomato 'HeZuo 908 Pink' plants were grown in a greenhouse at China Agricultural University under the same temperature and humidity settings as used in the growth chamber.

\section{Toxicity assay}

Toxicity of neonicotinoids was examined using both bioassay and HPLC analysis. The procedure was based on the optimized leaf immersion method (Wu et al. 2003). Briefly, insecticides were dissolved in dimethyl sulfoxide to make a stock solution with concentration of $10^{4} \mu \mathrm{g} /$ $\mathrm{mL}$. When used, the stock was further diluted into 100 , 
$50,20,10,5,2,1$, and $0.5 \mu \mathrm{g} / \mathrm{mL}$ using deionized water with $0.1 \%$ Tween 20 added. Ten grams of fresh tomato leaves collected from seedlings at 4-leaf stage were soaked in $300 \mathrm{~mL}$ of the above serial solutions and deionized water (control) respectively for $1 \mathrm{~h}$. The treated leaves were rinsed constantly for $3 \mathrm{~min}$ with deionized water to remove surface residual chemical. In the end, excessive water was removed using filter paper. The leaves were prepared in duplicates, with one set for bioassay, and another for HPLC analysis. The insecticidetreated leaf was referred as a toxic leaf.

A $500-\mu \mathrm{L}$ micro tube containing $1.5 \%$ water agar was prepared, with the lid having a hole punched. A toxic leaf was inserted into the tube with the petiole end embedded into the medium through the hole. The micro tube was then placed into a thimble tube $(15 \mathrm{~cm}$ in height and $1.5 \mathrm{~cm}$ in diameter), which was sealed with a cotton ball after moving 20 adult B. tabaci (Fig. 5). Fresh tomato leaves treated by deionized water were used as a control. Each treatment had 3 replicates. The materials were incubated for $48 \mathrm{~h}$ at $22-25^{\circ} \mathrm{C}$. The rate of mortality for the insects were counted by the number of live insects on treated plants devided by that on nontreated plants. The experiment was conducted twice.

\section{Safety assessment of insecticide tablets on tomato seedlings}

Insecticides and solid adjuvants were mixed adequately and pressed through mold to obtain a constant weight of $0.1 \mathrm{~g}$ per tablet, with active ingredient being 1, 2, 5, 10 and $15 \mathrm{mg}$ of either thiamethoxam, acetamiprid or nitenpyram respectively. A plastic tray $(540 \mathrm{~mm} \times 280 \mathrm{~mm})$ containing grids of cells was filled with soil (peat/vermiculite, $2: 1 \mathrm{v} / \mathrm{v}$ ) at $1 \mathrm{~cm}$ in thickness, followed by adding one tablet in each cell, and covered with $1 \mathrm{~cm}$ soil layer. Tomato seeds were sowed in the prepared soil in each cell. Tablets and seeds were spaced at least $3 \mathrm{~cm}$ in distance. The seedlings were grown in a greenhouse $\left(27 \pm 2{ }^{\circ} \mathrm{C}, 80 \% \mathrm{RH}\right.$ and $12 \mathrm{~h}$ photoperiod). Plant emergence and growth were evaluated.

\section{Uptake of insecticides in tomato plants}

The aboveground tomato seedlings treated with insecticides were collected at $7,14,21,28,35$, and 42 days after emergence and stored at $-20{ }^{\circ} \mathrm{C}$. Insecticides were detected qualitatively and quantitatively in the leaf samples using HPLC analysis as described above. The collected data were used to calculate the control effect, persistence, and the $\mathrm{LC}_{50}$ based on the uptake dynamic of insecticides.

\section{Effect of pesticide tablets on the control of B. tabaci and ToCV}

To detect the effect of nitenpyram tablet on controlling B. tabaci during the period of tomato seedling, pot

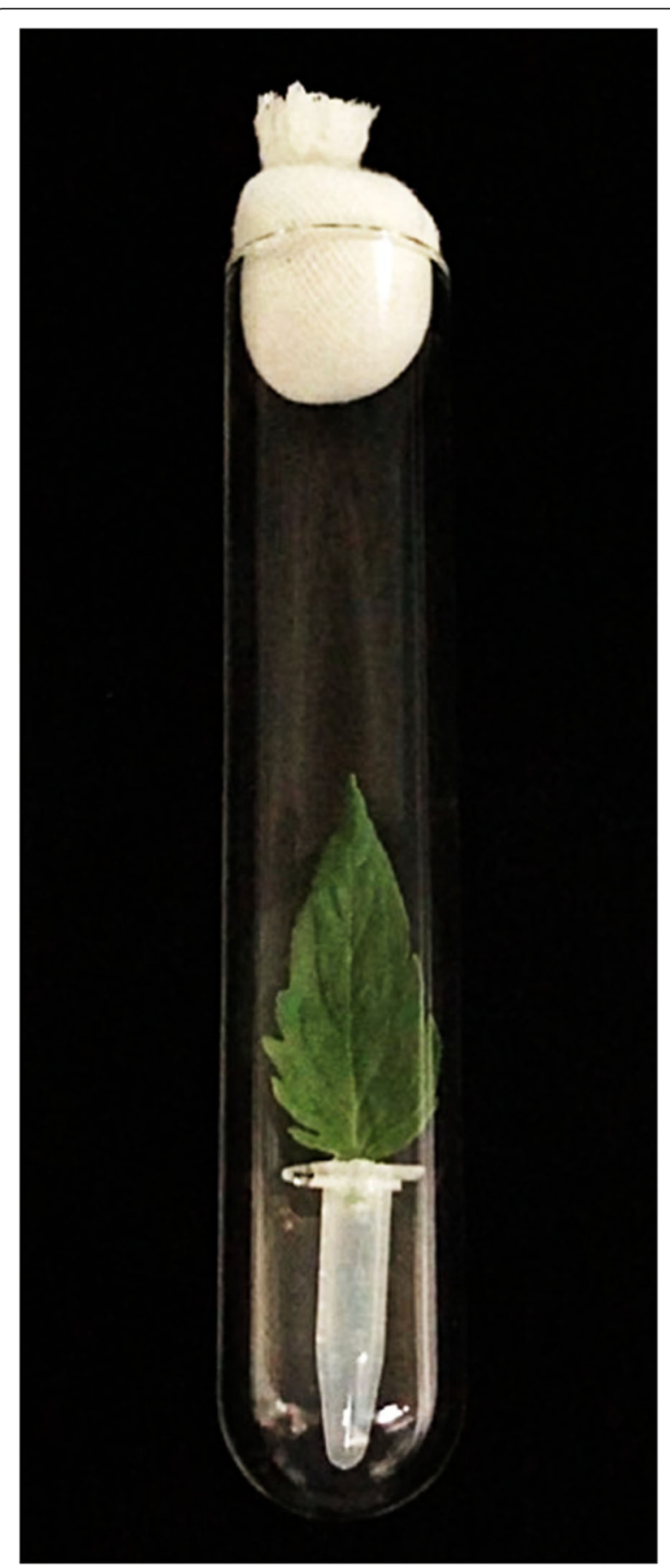

Fig. 5 Demonstration of bioassay. To maintain the freshness of leaves, plant leaflet was placed in a $0.5 \mathrm{~mL}$ centrifuge tube with the petiole in water agar. Insect sucking equipment was designed by connecting a rubber tube to a syringe, which was used to intake white flies from plant leaves and transfer into the test tube. There were 20 adult $B$. tabaci in each tube. The tube was covered with a cotton plug

experiments were carried out in a green house at China Agriculture University. At seeding, tablets containing 0 (control), 5, 10 and $15 \mathrm{mg}$ nitenpyram were buried under 
tomato seeds with $3 \mathrm{~cm}$ of soil in between and one tablet per seeding site in each seeding hole. In each treatment, 150 tomato plants were grown with 3 replications and a completely randomized design. Mortality was counted at 14,21 , and 28 days after sowing.

To test the persistency of control effect of pesticide tablets on B. tabaci and ToCV, field trials were conducted at Shouguang Vegetable Production Station from July 9 th to September 15th 2017. In the nursery facility, tablets containing 5 and $10 \mathrm{mg}$ nitenpyram were applied together with tomato seeds in seedling bed with one tablet per seeding site by the same method of pot experiments. After 28 days from sowing, emerged tomato seedlings were transplanted into a field, and placed with tablets of $40 \mathrm{mg}$ thiamethoxam (YITE ${ }^{\circ}$ ), which were buried about the same depth and $5 \mathrm{~cm}$ away from the bottom of the root in soil. Non-treated tomato seedlings were treated in three ways: 1 ) seedlings were placed with tablets of $40 \mathrm{mg}$ thiamethoxam at transplanting; 2) thiamethoxam (Actara ${ }^{\oplus}, 25 \%$ thiamethoxam WG) was applied on foliar at 7,14 and 24 days after the transplanting at $60 \mathrm{~g}$ a.i./ha; and 3) non-treated seedlings as a control. After transplanting, tomato seedlings were slightly watered to keep the soil moist and loose. The seedlings were watered for the first time at 7 days after planting and a minimal amount of water was added during drought before blossom. Each plot was sized with 50 $\mathrm{m}^{2}$ and had 200 tomato plants with 4 replications. The experiment was a randomized complete block design. Field management was carried out using a local standard production operation. The control efficacy of pesticides on B. tabaci and ToCV, and the disease index of ToCV was investigated at 32 and 46 days after transplanting. The trial was conducted twice.

The control effect on B. tabaci (IT\%) was as IT $=[(\mathrm{CK}$ - $\left.\left.\mathrm{IT}_{1}\right) / \mathrm{CK}\right] \times 100$, where $\mathrm{CK}$ is the number of live whiteflies, and $\mathrm{IT}_{1}$ is the number of live whiteflies treated with pesticides. To calculate the effect of pesticides against $\mathrm{ToCV}$, disease symptoms were categorized ( $\mathrm{Li}$ et al. 2016) from 9 levels: level 0: no symptoms; 1: several faded green spots appeared on part of basal leaves, or slight chlorosis spots shown along main veins, but the plant did not show dwarf symptom; 3: faded green spots appeared on the entire piece of basal leaves, but only basal leaves appeared yellowing, dwarf phenomenon was not obvious; 5: chlorosis appeared on the upper and lower leaves of the whole plant, plant was weak and dwarf, and the decrease of the yield of tomato fruit is $1 /$ 3; 7: etiolation phenomenon was badly on the leaves of whole plant, leaves became rigid, plant were dwarfed, and yield reduced by half; 9: etiolation phenomenon was badly on whole plant, the height of dwarf plant was less than $1 / 2$ of the normal plants, and it had no value to continue to grow. Disease index (DI) was calculated as
$\mathrm{DI}=\Sigma($ disease level $\times$ number of plants surveyed of each level)/ (The highest level $\times$ number of all plants surveyed) $\times 100$. The control effect of ToCV was calculated as $\mathrm{PT}=\left(\mathrm{DI}_{0}-\mathrm{DI}_{1}\right) / \mathrm{DI}_{0} \times 100$, where $\mathrm{PT}=$ control effect (\%), $\mathrm{DI}_{0}=\mathrm{DI}$ of control, and $\mathrm{DI}_{1}=\mathrm{DI}$ of pesticide treatment.

\section{Detection of insecticide content in tomato using HPLC}

Pesticides were extracted from neonicotinoid-treated leaves for HPLC analysis (Core 2003; Bilehal et al. 2016). Tomato plant tissues were frozen with liquid nitrogen and then crushed into fine powder. A 3-g powder sample was placed in a $50 \mathrm{~mL}$ polypropylene centrifuge tube. An aliquot of $3 \mathrm{~mL}$ of $\mathrm{ACN}$ with $\mathrm{ACOH} 1 \%$ was transferred into a tube and vortexed vigorously for $60 \mathrm{~s}$, and then $\mathrm{NaCl}(1 \mathrm{~g})$ was added. The mixture was handshaken for $30 \mathrm{~s}$, vortexed for $60 \mathrm{~s}$, and then centrifuged at $3040 \times \mathrm{g}$ for $10 \mathrm{~min}$. One milliliter of the supernatant (ACN phase) was transferred into a $1.5 \mathrm{~mL}$ centrifuge tube containing $50 \mathrm{mg}$ primary secondary amine (PSA), $10 \mathrm{mg}$ graphitized carbon blacks (GCB) and $100 \mathrm{mg}$ $\mathrm{Na}_{2} \mathrm{SO}_{4}$, but $50 \mathrm{mg} \mathrm{C} 18$ was replaced with $10 \mathrm{mg}$ of GCB for the extract of nitenpyram, then vortexed for 30 s. Subsequently, the extract was centrifuged again at $3040 \times g$ for $10 \mathrm{~min}$, and the supernatant was filtered into a glass tube through $0.45 \mu \mathrm{m}$ membrane. The sample was stored in a freezer at $-20^{\circ} \mathrm{C}$ for later use.

HPLC analysis was conducted by referring to published literatures (Abdel-Ghany et al. 2016; Vichapong et al. 2016). Chemical separation was performed with a Spuril $^{\mathrm{Tm}} \mathrm{C} 18(5 \mu \mathrm{m} \times 250 \mathrm{~mm} \times 4.6 \mathrm{~mm})$ column (Agilent Technologies, Beijing, China) at room temperature $\left(25 \pm 1^{\circ} \mathrm{C}\right)$. MilliQ (A) water and $\mathrm{MeOH}$ (B) were used as mobile phases, and the following gradient was $35 / 65$ (A/B) between 0 to $6 \mathrm{~min}$ for thiamethoxam and 0 to 12 min for nitenpyram and for acetamiprid, and after then changed to $0 / 100(\mathrm{~A} / \mathrm{B})$. Flow rate was $1 \mathrm{~mL} / \mathrm{min}$ and injection volume was $10 \mu \mathrm{L}$. Detection wavelength was $254 \mathrm{~nm}$ for both thiamethoxam and acetamiprid, and $260 \mathrm{~nm}$ for nitenpyram.

A calibration curve was established by analyzing spiked tomato plant matrices over a range of six concentrations from 0.1 to $100 \mu \mathrm{g} / \mathrm{g}$. The precision and repeatability were expressed as RSD (\%) of three concentrations for each chemical: 1,10 and $50 \mathrm{mg} / \mathrm{kg}$ for thiamethoxam and 5, 10 and $50 \mathrm{mg} / \mathrm{kg}$ for nitenpyram.

\section{Statistical analysis}

Data were analyzed using in SPSS statistical package (Version 25.0. Armonk, NY: IBM Corp., USA), and analysis of variance (ANOVA) was performed. Toxicity regression equations were established by correlating probit value of $B$. tabaci mortality rate and logarithm of the dose of insecticides, from which $\mathrm{LC}_{50}$ of the insecticides 
was derived. Means were separated by Fisher's multiple range test at significant level $\alpha=0.05$.

\section{Supplementary information}

Supplementary information accompanies this paper at https://doi.org/10. 1186/s42483-019-0044-4

Additional file 1: Table S1. Safety assessment of insecticide tablets on tomato seedlings.

\section{Abbreviations}

B. tabaci: Bemisia tabaci; GCB: Graphitized carbon blacks; HPLC: High performance liquid chromatography; $L_{50}$ : Effective $50 \%$ lethal concentration PSA: Primary secondary amine; RSD: Relative standard deviation; ToCV: Tomato chlorosis virus

\section{Acknowledgements}

The authors would like to thank the Institute of Vegetables and Flowers, Chinese Academy of Agricultural Sciences for providing whiteflies.

\section{Author details compliance with ethics quidelines}

Lei Li, Zhihong Hu, Tan Dai, Panqing Liu, Chen Chen, Pengfei Liu, Jiajin Guo, Hucheng Liu, Songlin Li, Jianjun Hao and Xili Liu declare that they have no conflict of interest or financial conflicts to disclose.

\section{Authors' contributions}

$\mathrm{LL}$ and $\mathrm{ZH}$ performed the experiments. All authors analyzed the data. PL and $\mathrm{XL}$ designed the study. $\mathrm{LL}$ and $\mathrm{ZH}$ wrote the manuscript. All authors read and approved the final manuscript.

\section{Funding}

This work was suported by National Key R\&D Program of China (2017YFD0201602) and special Fund for Agro-scientific Research in the Public Interest (201303028)

\section{Availability of data and materials \\ Not applicable.}

\section{Ethics approval and consent to participate}

Not applicable.

\section{Consent for publication}

Not applicable.

\section{Competing interests}

The authors declare that they have no competing interests.

\section{Author details}

'Department of Plant Pathology, China Agricultural University, Beijing 100193, China. ${ }^{2}$ Key Laboratory of Protected Vegetable Molecular Breeding, Shandong Vegetable Engineering Technology Research Center, Shouguang 262700, China. ${ }^{3}$ Baoding Shunnong Plant Protection Limited Company, Shunping County, Baoding 072250, China. ${ }^{4}$ School of Food and Agriculture, The University of Maine, Orono, ME 04469, USA.

Received: 4 October 2019 Accepted: 27 December 2019 Published online: 08 January 2020

\section{References}

Abdel-Ghany MF, Hussein LA, EL Azab NF, El-Khatib AH, Linscheid MW. Simultaneous determination of eight neonicotinoid insecticide residues and two primary metabolites in cucumbers and soil by liquid chromatographytandem mass spectrometry coupled with QuEChERS. J Chromatogr B. 2016; 1031:15-28.

Anderson JC, Dubetz C, Palace VP. Neonicotinoids in the Canadian aquatic environment: a literature review on current use products with a focus on fate, exposure, and biological effects. Sci Total Environ. 2015;505:409-22.
Bilehal DC, Chetti MB, Deepa GT, Khetagoudar MC. Multiresidue pesticide analysis using QuEChERS method in vegetable samples by ultra-performance liquid chromatography. Anal Chem Lett. 2016;6:688-96.

Byrne FJ, Toscano NC, Urena AA, Morse JG. Toxicity of systemic neonicotinoid insecticides to avocado thrips in nursery avocado trees. Pest Manag Sci. 2007:63:860-6

Castle S, Palumbo J, Prabhaker N. Newer insecticides for plant virus disease management. Virus Res. 2009;141:131-9.

Core J. Quechers method catches pesticide residues. Agric Res. 2003;51:9.

Dáder B, Legarrea S, Moreno A, Plaza M, Carmo-Sousa M, Amor F, et al. Control of insect vectors and plant viruses in protected crops by novel pyrethroidtreated nets. Pest Manag Sci. 2015;71:1397-406.

Douglas MR, Tooker JF. Large-scale deployment of seed treatments has driven rapid increase in use of neonicotinoid insecticides and preemptive pest management in US field crops. Environ Sci Technol. 2015;49:5088-97.

Ekbom B, Müller A. Flea beetle (Phyllotreta undulata Kutschera) sensitivity to insecticides used in seed dressings and foliar sprays. Crop Prot. 2011;30: 1376-9.

Gill RJ, Ramos-Rodriquez O, Raine NE. Combined pesticide exposure severely affects individual-and colony-level traits in bees. Nature. 2012;491:105-8.

Hallmann CA, Foppen RPB, van Turnhout CAM, de Kroon H, Jongejans E. Declines in insectivorous birds are associated with high neonicotinoid concentrations. Nature. 2014:511:341-3.

Huseth AS, Lindholm J, Groves CL, Groves RL. Variable concentration of soilapplied insecticides in potato over time: implications for management of Leptinotarsa decemlineata. Pest Manag Sci. 2014;70:1863-71.

Jeschke P, Nauen R, Schindler M, Elbert A. Overview of the status and global strategy for neonicotinoids. J Agric Food Chem. 2011;59:2897-908.

Kennedy TF, Connery J. Control of barley yellow dwarf virus in minimum-till and conventional-till autumn-sown cereals by insecticide seed and foliar spray treatments. J Agric Sci. 2012;150:249-62.

Kodandaram MH, Kumar YB, Banerjee K, Hingmire S, Rai AB, Singh B. Field bioefficacy, phytotoxicity and residue dynamics of the insecticide flonicamid (50 WG) in okra [Abelmoschus esculenta (L) Moench]. Crop Prot. 2017;94:13-9.

Li JJ, Zhuang QY, Yu Y, Zhang XX, Mao XH, Zhang AS. Preliminary study on control effect of several chemical pesticides on tomato chlorosis virus disease in solar greenhouse. China Vegetables. 2016;1(8):60-3 (in Chinese). http://www.cnveg.org/CN/abstract/abstract17424.shtml.

Orfanidou CG, Dimitriou C, Papayiannis LC, Maliogka VI, Katis NI. Epidemiology and genetic diversity of criniviruses associated with tomato yellows disease in Greece. Virus Res. 2014;186:120-9.

Prudnikova SV, Boyandin AN, Kalacheva GS, Sinskey AJ. Degradable polyhydroxyalkanoates as herbicide carriers. J Polym Environ. 2013;21:675-82.

Roditakis E, Stavrakaki M, Grispou M, Achimastou A, Van Waetermeulen X, Nauen $\mathrm{R}$, et al. Flupyradifurone effectively manages whitefly Bemisia tabaci MED (Hemiptera: Aleyrodidae) and tomato yellow leaf curl virus in tomato. Pest Manag Sci. 2017;73:1574-84.

Struger J, Grabuski J, Cagampan S, Sverko E, McGoldrick D, Marvin CH. Factors influencing the occurrence and distribution of neonicotinoid insecticides in surface waters of southern Ontario, Canada. Chemosphere. 2017;169:516-23.

Tolin SA, Fayad A. Virus diseases of tropical vegetable crops and their management. In: Muniappan R, Heinrichs E, editors. Integrated pest management of tropical vegetable crops. Dordrecht: Springer; 2016. p. 41-76.

Vichapong J, Burakham R, Srijaranai S. Alternative liquid-liquid microextraction as cleanup for determination of neonicotinoid pesticides prior HPLC analysis. Chromatographia. 2016;79:285-91.

Volova TG, Prudnikova SV, Zhila NO, Vinogradova ON, Shumilova AA, Nikolaeva $E D$, et al. Efficacy of tebuconazole embedded in biodegradable poly-3hydroxybutyrate to inhibit the development of Fusarium moniliforme in soil microecosystems. Pest Manag Sci. 2017;73:925-35.

Wang R, Zhang W, Che W, Qu C, Li F, Desneux N, et al. Lethal and sublethal effects of cyantraniliprole, a new anthranilic diamide insecticide, on Bemisia tabaci (Hemiptera: Aleyrodidae) MED. Crop Prot. 2017;91:108-13.

Wintermantel WM, Wisler GC. Vector specificity, host range, and genetic diversity of tomato chlorosis virus. Plant Dis. 2006;90:814-9.

Wu QJ Xu BY, Zhang YJ, Zhu GR. Toxicity and field efficacy of thiamethoxam to Bemisia tabaci with different methods of treatment. Chin J Pestic Sci. 2003; 5(4):70-4 (in Chinese). http://www.nyxxb.cn/article/id/20030412.

Zhang Y. Novel pesticide tablets. World Pesticides. 1993;6:9 (in Chinese). 
Zhao RN, Wang R, Shi YC, Zhang GJ, Yuan K, Fan ZF, et al. Molecular identification of Tomato chlorosis virus on sweet pepper. Plant Prot. 2014; 40(1):128-30 (in Chinese). http://en.cnki.com.cn/Article_en/CJFDTotal-ZWBH2 01401024.htm.

Zheng H, Xie W, Wang S, Wu Q, Zhou X, Zhang Y. Dynamic monitoring (B versus Q) and further resistance status of Q-type Bemisia tabaci in China. Crop Prot. 2017;94:115-22.

Ready to submit your research? Choose BMC and benefit from:

- fast, convenient online submission

- thorough peer review by experienced researchers in your field

- rapid publication on acceptance

- support for research data, including large and complex data types

- gold Open Access which fosters wider collaboration and increased citations

- maximum visibility for your research: over $100 \mathrm{M}$ website views per year

At $\mathrm{BMC}$, research is always in progress.

Learn more biomedcentral.com/submissions 